\title{
POSSIBILITIES OF CLEANING OF METAL SPONGE CASTINGS
}

\author{
Václav MERTA \\ VSB - Technical University of Ostrava, Ostrava, Czech Republic, EU \\ vaclav.merta@vsb.cz
}

https://doi.org/10.37904/metal.2019.970

\begin{abstract}
The paper deals with methods of cleaning metal sponge castings. This type of metal foam materials, which is unique amongst other types by having fully interconnected and open pores, is produced by a two-step investment casting process using an evaporative polyurethane pattern. A special gypsum compound is used as a mould making material that is able to completely fill the complex pore system during moulding. However, after casting, the moulding material has lower collapsibility (higher residual strength). For this reason, there is a problem with the removal of mould residues from individual pores. Therefore, various alternative methods of cleaning this type of casting have been designed and tested in the experiment.
\end{abstract}

Keywords: Metal sponge, investment casting, gypsum moulding materials, cleaning methods

\section{INTRODUCTION}

Metal foams are currently a very progressive group of materials. These are porous metallic materials with cellular structure. The pores are purposely produced in the structure of these materials, the size and distribution of pores in the metal matrix depends on the particular manufacturing method. To date, a number of different manufacturing processes have been developed to obtain metal foams with pores of different sizes, with closed porosity or open fully interconnected pores, with regular or stochastic pore arrangement [1]. Thanks to this porous structure, these materials excel in a number of specific mechanical and functional properties. For example, high specific stiffness or the ability to absorb large amounts of deformation energy are used in the manufacture of lightweight structural or deformation zones components, especially in the automotive and aerospace industries. Other specific properties are then used in a variety of functional applications. Unique thermal control properties give unprecedented possibilities in the production of heat exchangers and coolers, as well as thermal insulation materials. The large specific surface area of open and fully bonded pores is then advantageous in the manufacture of catalyst carriers or electrodes for rechargeable batteries [2].

One of the frequent ways of producing these materials is the use of conventional or special foundry technologies. The basic principle in this production is that the porous structure is obtained by casting the liquid metal into a foundry mould in which the future pores are formed by the moulding material itself. Regardless of the particular technology used, after the solidification of the metal, a composite material is obtained which is formed of metal and the moulding material used. It is therefore necessary to remove the moulding material from the pores to obtain the metal foam itself. In some cases this can be achieved quite easily, for example, using water-soluble salt moulding materials [3]. When using conventional sand moulds and cores, care must be taken to select moulding material with good collapsibility after casting. Perhaps the most complicated situation is in the case of investment castings of metal sponges, where the gypsum-based moulding compound is most commonly used. Depending on the annealing temperature, these mixtures usually have relatively poor or very poor collapsibility and high residual strength after casting. Another complication is the structure itself. The relatively small and in particular variable size, random distribution and different interconnection rates of the individual pores, in combination with the thin-walled metal matrix structure, make these castings difficult to clean. 
The aim of this experiment was to optimize the process of cleaning metal sponge castings, which is produced by the two-stage investment casting process using an evaporative polyurethane model.

\section{EXPERIMENTAL PART}

Within the experiment metal sponge samples were cast from aluminium alloy and copper alloy. Different cleaning methods were then tested on these samples and their efficiency, time requirements, and other factors, such as hygiene conditions in the cleaning process, were evaluated.

\subsection{The two-stage investment casting process using an evaporative PUR pattern}

The principle of this manufacturing method (Figure 1) is to embed a pattern of polymer foam with a suitable refractory material, followed by drying and annealing of the mould. During the annealing, the foam pattern evaporates. This forms a cavity in which molten metal is subsequently cast. After removal of the refractory material, cast metal foam is obtained, which is an exact copy of the foam pattern [4-6].
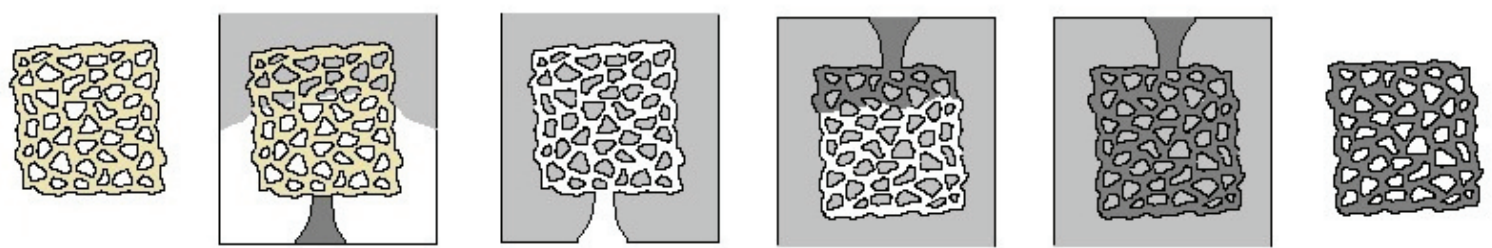

Figure 1 Principle of the two-stage investment casting process using an evaporative polyurethane (PUR) pattern [6]

\subsection{Sample castings manufacturing}

Test casting was designed as $50 \times 50 \times 20 \mathrm{~mm}$ sample of sponge with gating through the solid wall. [7] Reticulated polyurethane foam Bulpren S 32450 (Eurofoam TP, s.r.o., CZ) with a 10 ppi porosity was used as a pattern. The solid wall pattern was made from injection wax Aqua green (SRS - Ltd., GB). Figure 2 shows prepared pattern. Special gypsum composite Eurovest (SRS - Ltd., GB) was used as the moulding material. The annealing cycle recommended by the manufacturer has been followed. After last hold, the moulds were further heated or cooled to a final temperature to be cast. The optimum mould temperature was found to be $540{ }^{\circ} \mathrm{C}$ for aluminum alloy AISi $10 \mathrm{MgMn}$ castings, and $950{ }^{\circ} \mathrm{C}$ for copper alloy CuSn12 castings. The casting process was carried out on a special Indutherm MC15 casting machine. This allows melting and casting under vacuum (98 kPa) while solidifying under superatmospheric pressure $(200 \mathrm{kPa})$. After casting and solidification of the castings, the moulds are disrupted by thermal shock, whereby most of the moulding material is removed by immersing still warm moulds in the water bath. The resulting castings before cleaning are shown in Figure 3 and Figure 4.

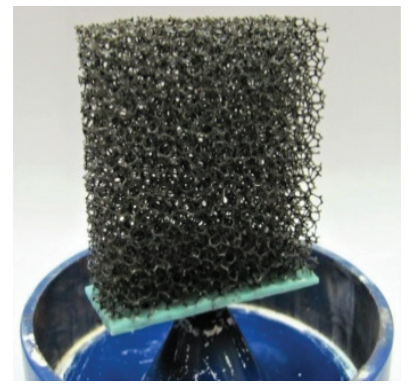

Figure 2 Prepared PUR pattern with wax solid wall

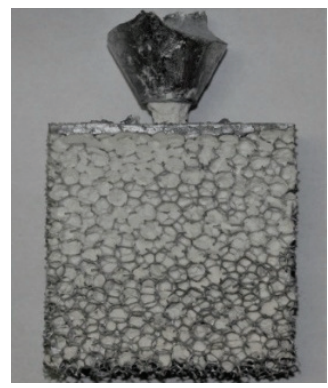

Figure 3 AISi10MgMn sponge casting after mould removal

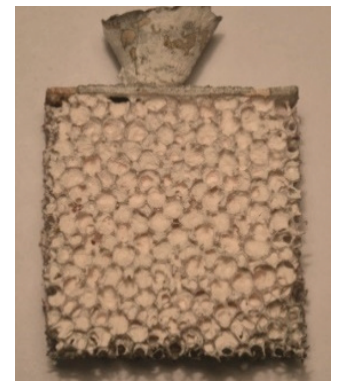

Figure 4 CuSn12 sponge casting after mould removal 


\subsection{Sample castings manufacturing}

As shown in Figure 3 and Figure 4, after the casting is removed from the mould, a considerable amount of the gypsum compound used remains in the pores of the cast metal sponge to be removed from the casting. Due to the very fine construction of these castings (the thickness of the individual ligament of about $0.3 \mathrm{~mm}$ ) and already mentioned poor collapsibility of the moulding material used, these gypsum compound residues cannot be removed by simple mechanical agitation eg. by vibration. It is therefore necessary to use other more complicated methods to clean these castings.

Based on previous research a method of chemical disruption was used at first. The castings were leached in $1 \mathrm{M}$ nitric acid $\left(\mathrm{HNO}_{3}\right)$ solution, where the insoluble calcium sulphate dihydrate $\mathrm{CaSO}_{4} \cdot 2 \mathrm{H}_{2} \mathrm{O}$ was converted to water soluble calcium nitrate $\mathrm{Ca}\left(\mathrm{NO}_{3}\right)_{2}$. Subsequently, the castings were finally cleaned in a Laborrete 17 ultrasonic bath (Fritsch $\mathrm{GmbH}, \mathrm{DE}$ ). However, the entire process is very time-consuming - at least 1 hour of leaching in $\mathrm{HNO}_{3}$ and 1 hour of cleaning in ultrasonic bath were needed to completely clean the casting. At the same time, this process entails a great environmental burden due to the acid used.

Therefore, a suitable replacement for this process was sought. The authors $[7,8]$ mention the possibility of using pressurized water for cleaning these castings. This method was tested using a Patriot PW 110 pressure washer with a maximum working pressure of $10 \mathrm{MPa}$. As an alternative to this variant, the use of 10 bar compressed air was also tested.

\section{RESULTS}

Some disadvantage of tested cleaning methods using pressurized water or compressed air is that there are some small areas in the vicinity of the solid wall of the metal sponge casting from which it is not possible to remove the gypsum compound residues by these methods. Thus, the use of acid is necessary for final cleaning. However, much smaller amounts of residual gypsum compound need to be removed and a considerably lower consumption of acid and shorter leaching time are sufficient. In addition, in case of removing the solid wall as an element of the gating system, this problem is irrelevant.

Table 1 The results of comparison of two tested cleaning processes

\begin{tabular}{|c|c|c|c|c|c|c|}
\hline \multirow{2}{*}{$\begin{array}{l}\text { Cleaning } \\
\text { process }\end{array}$} & \multicolumn{3}{|c|}{ Pressurized water cleaning } & \multicolumn{3}{|c|}{ Compressed air cleaning } \\
\hline & \multicolumn{3}{|c|}{ Gypsum compound residues (g) } & \multicolumn{3}{|c|}{ Gypsum compound residues (g) } \\
\hline $\begin{array}{l}\text { Casting } \\
\text { material }\end{array}$ & $\begin{array}{l}\text { Removed } \\
\text { after cleaning }\end{array}$ & $\begin{array}{c}\text { Removed } \\
\text { after } \mathrm{HNO}_{3} \\
\text { and ultrasonic } \\
\text { cleaning }\end{array}$ & In total & $\begin{array}{l}\text { Removed } \\
\text { after cleaning }\end{array}$ & $\begin{array}{c}\text { Removed } \\
\text { after } \mathrm{HNO}_{3} \\
\text { and ultrasonic } \\
\text { cleaning }\end{array}$ & In total \\
\hline \multirow{3}{*}{ AISi10MgMn } & 40.7 & 1.1 & 41.8 & 41.0 & 0.6 & 41.6 \\
\hline & 39.6 & 0.7 & 40.3 & 38.5 & 0.5 & 39.0 \\
\hline & 41.3 & 0.9 & 42.2 & 40.5 & $0-7$ & 41.2 \\
\hline$\varnothing$ & 40.5 & 0.9 & 41.4 & 40.0 & 0.6 & 40.6 \\
\hline \multirow{3}{*}{ CuSn12 } & 32.6 & 2.7 & 35.3 & 34.5 & 1.4 & 35.9 \\
\hline & 33.8 & 2.6 & 36.4 & 32.4 & 1.9 & 34.3 \\
\hline & 33.7 & 2.3 & 36.0 & 34.0 & 1.6 & 35.6 \\
\hline$\varnothing$ & 33.4 & 2.5 & 35.9 & 33.6 & 1.6 & 35.3 \\
\hline
\end{tabular}

Given the size of samples has to be cleaned both pressurized water cleaning and compressed air cleaning shows quite similar effectiveness with small differences. The results are summarized in Table 1. The average 
amount of residual gypsum compound remaining in the pores of casting was $41 \pm 0.9 \mathrm{~g}$ for AISi10MgMn castings and $35.6 \pm 0.5 \mathrm{~g}$ for CuSn12 castings. This relatively big difference on same sample size could be caused by different annealing temperatures and thus different ability on chemical bonding with water during mould removal in water bath. Compared to the previous mentioned $\mathrm{HNO}_{3}$ cleaning method, both these methods seems to be much more time efficient. Instead of 2 hours of acid leaching and ultrasonic cleaning the casting can be cleaned within 2-3 minutes. If the final step of acid leaching is necessary it takes for about 15 minutes and another 15 minutes for ultrasonic cleaning. The castings after final cleaning are shown in Figure $\mathbf{5}$ and Figure 6.

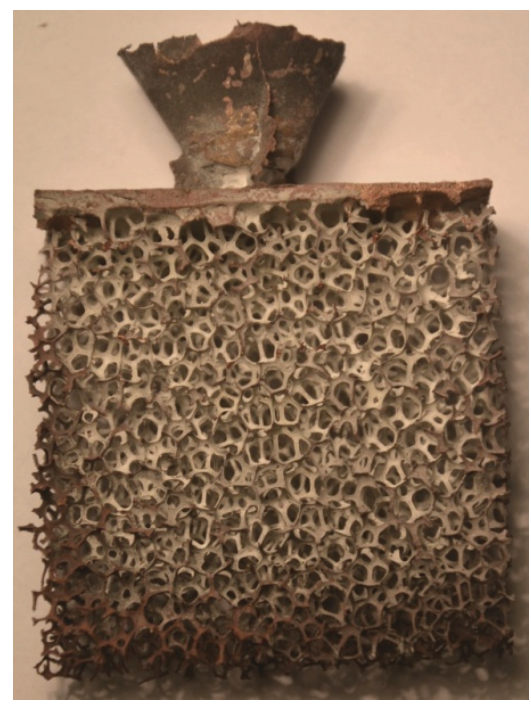

Figure 5 CuSn12 sponge casting after 3 minutes of pressurized water cleaning, 15 min of leaching in $1 \mathrm{M} \mathrm{HNO}_{3}$ solution and 15 min of ultrasonic cleaning

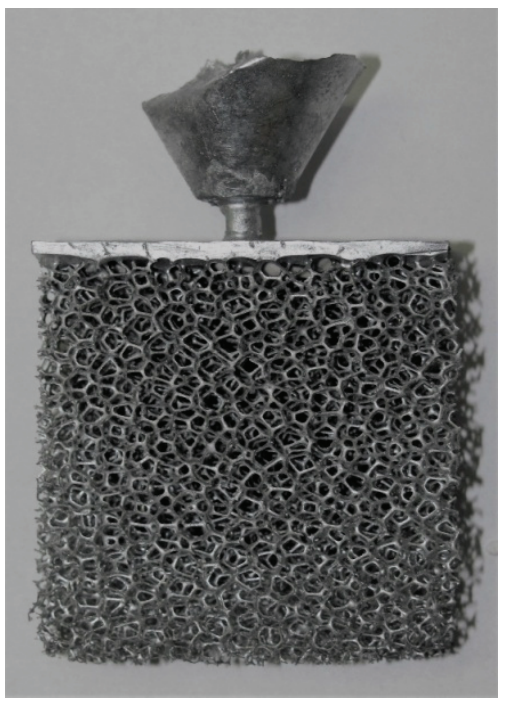

Figure 6 AlSi10MgMn sponge casting after 2 minutes of compressed air (10 bar) cleaning, 15 min of leaching in $1 \mathrm{M} \mathrm{HNO}_{3}$ solution and 15 min of ultrasonic cleaning

Average time to clean both aluminium alloy and copper alloy sponge castings was approximately 3 min using pressurized water (PW) and 2 min using compressed air (CA). After this time only about from $1.5 \%$ (CA) to $2.2 \%$ (PW) of gypsum compound residues remains in AlSi10MgMn castings and from $4.5 \%$ (CA) to $7 \%$ (PW) in CuSn12 castings. The differences between amount of difficult to clean part of moulding material are probably caused by the worse collapsibility of the moulding material which was annealed on higher temperature due to modification changes of $\mathrm{CaSO}_{4}$ and of course by the cleaning technology itself. From the results it could be seen that the CA process is more effective. However, this method might be dimension limited nearby the dimensions of test castings used in this experiment. It is also very dusty process and has to be done in closed cabin with suction. On the other hand PW process has also some technological disadvantages for example relatively big consumption of water.

\section{CONCLUSION}

Some of the possibilities of cleaning metal sponge castings were tested during this experiment. The previously tested method of chemical disintegration of gypsum moulding material residues with nitric acid is not entirely technologically, economically or ecologically suitable for removing the entire amount of residual moulding material. Cleaning in the ultrasonic bath is not effective enough and can only be considered as a complementary method.

On contrary, tested methods of cleaning by pressurized water or compressed air seems to be very effective and time efficient. In addition, the impact of the cleaning process on environment is negligible compared to the 
use of acid. However, even these methods have their disadvantages, such as the dimensional limits of cleanable castings, or the energy intensity. For getting better knowledge on this problematic further more detailed research should be done.

\section{ACKNOWLEDGEMENTS}

The contribution was worked out with the support of the Technology Agency of the Czech Republic TH02020668 and projects of "Student Grant Competition" numbers SP2019/148 and SP2019/43. The author Václav Merta is "City of Ostrava scholarship" holder.

\section{REFERENCES}

[1] BANHART, John. Manufacture, characterisation and application of cellular metals and metal foams. Progress in Materials Science. 2001. vol. 46, no. 6, pp. 559-632.

[2] GARCÍA-MORENO, Francisco. Commercial Applications of Metal Foams: Their Properties and Production. Materials. 2016. vol. 85, no. 9.

[3] ASHBY, Michael F. Metal Foams: A Design Guide. Massachusetts: Butterworth-Heinemann. 2000. p. 251, ISBN: 9781493302918.

[4] LICHÝ, Petr, ELBEL, Tomáš, KROUPOVÁ, Ivana and RADKOVSKÝ, Filip. Preparation and evaluation of properties of cast metallic foams with regular inner structure. Archives of Metallurgy and Materials. 2017. vol. 62, no. 3, pp. 1643-1646. ISSN 1733-3490.

[5] KROUPOVÁ, Ivana, LICHÝ, Petr, LIČEV, Lačezar, HENDRYCH, Jakub and SOUČEK, Kamil. Evaluation of Properties of Cast Metal Foams with Irregular Inner Structure. Archives of Metallurgy and Materials. 2018. vol. 63, No. 4, pp. 1845-1849. ISSN 1733-3490.

[6] KROUPOVÁ, Ivana, LICHÝ, Petr, RADKOVSKÝ, Filip, BEŇO, Jaroslav, BEDNÁŘOVÁ, Vlasta and LÁNA, Ivo. Optimization of the annealing of plaster moulds for the manufacture of metallic foams with an irregular cell structure. Materiali in Tehnologije. 2015. vol. 49, No. 4, pp. 527-530. ISSN 1580-2949.

[7] WANG, L., LI, H., WANG, F. and REN, J. Preparation of the open pore aluminum foams using investment casting process. Acta Metallurgica Sinica (English Letters). 2001, vol. 14, no. 1, pp. 27-32.

[8] MATZ, A. M., MOCKER, B. S., MÜLLER, D. W., JOST, N. and EGGELER, G. Mesostructural design and manufacturing of open-pore metal foams by investment casting. Advances in Materials Science and Engineering. 2014. pp. 1-9, 421729. 